\title{
А.Е. Баженова
}

\section{СКАЗКА В ОТЕЧЕСТВЕННОЙ КНИЖНОЙ ГРАФИКЕ 1960-1980-х ГГ. СВЯЗЬ ИЛЛЮСТРАЦИИ И ТЕКСТА}

\begin{abstract}
В статье анализируется взаимосвязь детской классической сказки и иллюстрации в творчестве отечественных художников в 1960-1980-х г2. с учетом различных факторов: времени создания литературного произведения, исторического контекста, адекватности художественного и лингвистического переводов, индивидуального стиля художника, категорий пространства и времени, а также изменения восприятия иллюстрированной сказки в современном обществе.

Ключевые слова: иллюстрация, детская сказка, интерпретация образов, визуальная культура.
\end{abstract}

Проблемы связи иллюстрации с литературным произведением неоднократно находили свое отражение в трудах отечественных исследователей: В.Н. Ляхова, Н.А. Дмитриевой, О.И. Подобедовой, Э.З. Ганкиной, И.Г. Хангельдиевой и др. Анализируя творческие методы иллюстраторов, подходы к интерпретации образов героев с позиций писателя и художника, оценивая категории пространства и времени в литературе и иллюстрации, они основывались на опыте иллюстрирования преимущественно классических литературных произведений. Специалисты редко касались аналогичных вопросов, связанных с творчеством отечественных художников детской сказки. Это связано, главным образом, со временем появления основной массы исследований, посвященных синтезу изображения и слова - 1960-1970-е гг., когда в искусстве иллюстрации детской сказки происходит переосмысление основополагающих принципов, целей, правомерности индивидуальной интерпретации произведения и творческих методов. Отсутствие четкого видения перспектив дальнейшего развития и разработанного методологического аппарата не позволило объективно проанализировать особенности связи произведений сказочного жанра и иллюстрации.

Формирование специфики искусства иллюстрации детской сказки в 1960-1980-е гг. занимает особое место в истории развития отечественной книжной графики в целом. Развитие международных связей в области изобразительного искусства и литературы во второй половине 1950-х гг. открывало перед молодыми художниками не только новые горизонты в изобразительном искусстве, но и ставило ещё более сложные задачи по сравнению с предыдущим историческим периодом.

Переосмысление сюжетов западной детской литературы происходит в среде отечественных иллюстраторов, писателей и переводчиков. Особенность интерпретации зарубежных сказок заключается в том, что прежде чем быть проиллюстрированными в том или ином своем переиздании, их текст переводится. Таким образом, художник, как правило, иллюстрирует адаптированный перевод литературного произведения. В связи с этим возникает 
конфликт лингвистического и художественного переводов. Тонкие нюансы языкового смысла отражают культурные и национальные особенности его носителей. По мнению А.Ю. Исаковской, главной целью в процессе адаптации текстов зарубежных сказок является стремление переводчика «нивелировать межкультурные различия» [1. С. 13]. Таким образом, в 1930-1960-х гг. формируется жанр творческой интерпретации [Там же. С. 2], где сюжеты мировой детской литературы представлены уже в авторской трактовке отечественных писателей. В первом случае художник чаще всего косвенно взаимодействует не только с писателем и его оригинальной идеей, но и с переводчиком, чья трактовка первоисточника также влияет на восприятие литературного произведения. В случае с творческой интерпретацией задача иллюстратора состоит в том, чтобы сохранить в изображении самобытность сюжета, представленного в ином пространственно-временном и культурном соотношении.

Изложение художником собственного видения фабулы произведения, образов героев, исторической эпохи, на фоне которого разворачиваются события, и социокультурных условий относительно современного уровня развития общества зависит в свою очередь от особенностей его стиля и творческих методов. Например, интерпретация образа Алисы из произведения Л. Кэрролла «Алиса в стране чудес» со времен первого издания на русском языке претерпела множество метаморфоз, отойдя от его изначального описания автором. Лаконичны акварельные этюды М.П. Митурича-Хлебникова с ограниченной цветовой гаммой, в которых Алиса предстает в виде силуэта девочки монохромно голубого цвета, подчеркивающего меланхолическое настроение сказки и метафоричность сюжета. Ю.А. Ващенко в свое время изобразил Алису в манере первого наброска, несколько небрежного и раскрашенного. Героиня здесь высокая, даже долговязая девушка-подросток с большими глазами и чрезмерно длинной шеей. Она вызывает цветовые аллюзии в иллюстрациях, вызванные её горчично-желтым длинным платьем, которого не было в описании Кэрролла.

Личное отношение к образу главной героини выражает и художник Г.В. Калиновский, иллюстрировавший произведение Кэрролла несколько раз. Каждая из версий Калиновского является переосмыслением идеи писателя с различных позиций времени, пространства и психологического состояния персонажей. Художники отходят не только от ставшего уже каноническим в западноевропейской иллюстрации образа любопытной светловолосой девочки Алисы в платье с фартуком, но и уделяют значительное внимание характеру героини, её эмоциональному и психофизическому состоянию.

Индивидуальная интерпретация художником литературного произведения, в данном случае зарубежной классической сказки, может иметь как положительный эффект в виде нового прочтения сюжета, адаптации образов с учетом национальных и культурных особенностей, так и отрицательный в виде приближенного к фабуле произведения пересказа, искаженного восприятия оригинального замысла автора, а также формирования у читателей культурных и исторических стереотипов. В середине 1970-х гг., советский иллюстратор В.И. Таубер в своей статье, посвященной иллюстрированию сказок братьев Гримм, ставит вопрос о том, можно ли определить право на 
существование той или иной «остро индивидуальной трактовки» [2. С. 76] классической сказки или нет. Отнюдь не каждая новая серия иллюстраций художников к мировым сюжетам сказочной литературы может быть действительно актуальной для своего времени, открывающей другую сторону произведения и личности его автора.

Проблема соответствия творческого метода иллюстратора выразительным средствам, которые писатель использует в литературном произведении, в целом оказывает значительное влияние на восприятие читателем определенной сказки. Скажем, Ю.Н. Тынянов считал, что иллюстрация нарушает целостность восприятия литературного произведения, «изымая из произведения фабульную деталь» [3. С. 317], при этом разрывая сюжетную линию акцентировкой на малозначительные сцены. По его мнению, невозможно воплотить живое слово писателя в изображении или скульптуре, которые переводят текст в область конкретного предмета, материала или действия. Возможная форма объективного сосуществования изображения и слова, по Тынянову, - это рисунок, который подчиняется конструктивным принципам выбранного литературного произведения или служит неким графическим эквивалентом слову, исполняя его функции [Там же. С. 316].

Однако при иллюстрировании детских классических сказок формирование целостного художественного образа зависит от ряда факторов, в том числе и от соответствия жанрового и стилистического принципов между произведением и иллюстрацией [4. С. 178]. Учитывая метафоричность сюжета и характерные черты сказочных персонажей, художник подстраивается под стиль изложения писателя, особенности используемых им средств выразительности. Отсутствие у художника соответствующих произведению визуальных ассоциаций ведет к искажению литературных образов в сознании читателя. Иллюстрация становится неким «фоновым» изображением, не несущим смысловой нагрузки и не способным вызвать эмоциональный отклик.

Помимо жанра как типа литературного произведения и стиля, как мировоззренческой категории, важную роль в переложении на язык графики играет время действия [Там же. С. 8]. Изображение в иллюстрации другого исторического периода, культуры и быта требует от художника не просто соответствующих знаний, но и умения выразить атмосферу времени, присущую классической сказке. В этой связи одной из отличительных черт иллюстраций детских сказок 1960-1980-х гг. является внимание к достоверному изображению атрибутов эпохи. Художникам уже было недостаточно писательской информации, и они стали искать помощи в историческом контексте. Убедительность изображения интерьеров, костюмов, архитектуры и быта всё это позволило под другим углом увидеть иллюстрацию детской сказки и труд самого художника. Тем не менее подобный отход иллюстраторов нового поколения от привычного изображения сказочных героев крупным планом, без детализации антуража, вызвал разногласия в среде деятелей искусства. Подмена достоверности в иллюстрировании различных исторических эпох подражательностью мировым стандартам и стилизациией в 1970-1980-х гг. стала частым явлением [5. С. 79].

Иллюстрированная детская классическая сказка познакомила читателей с зарубежной культурой разных эпох. Однако качество иллюстраций зависе- 
ло здесь не только от мастерства художника, но и от его способности вникать в подтекст литературного произведения, находя в нём аналоги современным реалиям. Большое количество подражательных иллюстраций, наполненных красочным фальшивым лоском, появилось на рынке отечественной книжной продукции во второй половине 1980-1990-х гг. Проблема кроется не только в упрощенном восприятии сюжета, вульгаризации стиля графического изложения произведения и развитии дурного вкуса у подрастающего поколения, но и в формировании различного рода штампов и культурных стереотипов.

Уделяя внимание достоверности в передаче деталей и образов других исторических эпох, художник не должен упускать и другой немаловажный аспект - объективное отражение категорий времени и пространства в сказке. В своё время немецкий поэт и теоретик искусства Г.Э. Лессинг предложил оставить поэтам описание последовательности событий во времени, а художникам доверил изображение пространства [6. С. 444]. При создании иллюстраций художник может изобразить лишь отдельно взятые ключевые моменты, которые в своей ритмической последовательности по отношению к сюжету литературного произведения позволяют читателю выстроить канву событий в их общую картину. Особенность иллюстрирования сказок заключается ещё и в том, что помимо изображения и визуального истолкования очевидных действий необходимо учитывать их скрытый подтекст, отданный на откуп читательского воображения.

Определенное влияние на организацию пространства детской сказочной иллюстрации и вопросы создания иллюзии движения во времени, как и развития сюжета, оказали мультипликация, кинематограф и комиксы. Исходя из принципа кинематографичности, иллюстрации представляют собой кадры, каждый из которых содержит какой-то эпизод произведения [7. С. 188]. Логически связанные сюжетом фрагменты, следующие друг за другом, создают тот самый эффект динамичного развития событий, позволяющий читателю не нарушать литературно-образную целостность произведения. Высказанные в свое время Ляховым прогнозы относительно широкого распространения методов кинематографа и комиксов в построении композиции и разработки способов отображения пространственно-временных отношений в книжной иллюстрации постепенно стали частью обыденной реальности современного искусства книги.

Развитие компьютерных технологий привело к тому, что на сегодняшний день иллюстрация детской классической сказки является частью пространства, которое в западноевропейской историографии принято называть Visual culture. Изменение социальных условий и исторического времени неизбежно повлекли за собой формирование иного отношения к книжным иллюстрациям и литературному наследию как таковому. Противоречивый по своему характеру процесс перевода текстовой информации на язык визуальных коммуникаций стал своеобразной калькой для развития аналогичного явления во взаимоотношениях слова и изображения. Перенасыщенность информационного поля послужила причиной бесконечных комбинаций известных форм [8. С. 199], заложенных в основу творческого метода подавляющего числа современных иллюстраторов детской сказки. 
Таким образом, отечественная иллюстрация, достигшая своего апогея в 1970-1980-х гг. и неразрывно связанная с основной идеей писателя и сюжетом сказки, на нынешнем этапе развития книжной графики воспринимается отдельно от литературного произведения, либо как вариант оформления, либо как самостоятельное изображение. Исследователи склонны недооценивать значение литературно-образного единства, сводя предмет искомого изучения к литературоведческому анализу и семиотике, при этом нивелируя значение иллюстрации в искусстве книги и современной культуре в целом.

\section{Литература}

1. Исаковская А.Ю. Детская сказка в русской советской литературе (рецепция мировых сюжетов) : автореф. дис. ... канд. филол. наук. М., 2012. 26 с.

2. Таубер В.И. О старой немецкой сказке (Об иллюстрации сказок братьев Гримм) // Детская литература. 1975. № 8. С. 75-79.

3. Тынянов Ю.Н. Иллюстрации // Поэтика. История литературы. Кино. М. : Наука, 1977. C. $310-318$.

4. Подобедова О.И. О природе книжной иллюстрации. М. : Советский художник, 1973.335 с.

5. Баженова A.E. Конфликт поколений или смена приоритетов в искусстве иллюстрации детской книги // В мире науки и искусства : вопросы филологии, искусствоведения и культурологии : сб. ст. по матер. XLVI Междунар. науч.-практ. конф. Новосибирск : Изд-во СибАК, 2015. № 3 (46). C. 77-81.

6. Лессинг Г.Э. Избранное / пер. с нем.; вступ. статья и коммент. А. Гулыги. М. : Художественная литература, $1980.574 \mathrm{c}$.

7. Ляхов В.Н. Искусство книги. Избранные историко-теоретические и критические работы. М. : Советский художник, 1978. 248 с.

8. Дианова В.М. Постмодернистская философия искусств : истоки и современность. СПб. : Петрополис, 2000. 240 c.

Bazhenova Anastasia E. Herzen State Pedagogical University of Russia (Russian Federation, St. Petersburg).

E-mail: nastyabagenova @ gmail.com

Tomsk State University Journal of Cultural Studies and Art History, 2017, № 25. 76-81 pp.

DOI: $10.17223 / 22220836 / 25 / 9$

FAIRYTALE IN THE DOMESTIC BOOK GRAPHICS 1960-1980 YEARS. COMMUNICATION ILLUSTRATIONS AND TEXT

Key words: illustration, children's story, the interpretation of the images, historical context, visual culture.

The problem of the relationship of literature and illustration is one of the most pressing since the first picture books, particularly children's classic fairy tales. Modern scholars tend to underestimate the importance of illustration in conjunction with the literary work, virtually eliminating it from the book space. Most of the works in Russian historiography devoted to the synthesis of images and words appeared in the 1960-1970-ies. During this period in art illustration children's classic tale is redefining the fundamental principles of creative techniques and figurative-expressive means.

The first factor that affects the connection between the nature of the illustration and the text of a literary work - is the adequacy of the artistic and linguistic translation. Since foreign illustrating tales involves the interaction of the artist is not so much with the original idea of the author as to its interpretation adapted. The accuracy of the description of space and time in a literary work, as well as the historical context, as if binding of the writer and the artist, the degree of reliability depends illustration. Full illustration of another historical period, culture and life, requires from the artist not only relevant knowledge, but also the ability to express the atmosphere of the time inherent in the classic fairy tale. Adjusting to the style of the writer, and particularly funds used by the expressiveness, the artist creates visual association related to the presentation of works. Inconsistency images and tales of the plot, it leads to a distorted perception in the minds of readers, as well as a violation of the integrity of the book. A huge influence on the development of children's fairy tale illustrations during the second half of the XX century had an animation cinema and comics. Based on the principle of the movies, each 
scene is described in a product, is the frame. Taken together, and often replacing each other, these images create the effect of dynamic actions.

It should also be noted that the change in social conditions and historical time resulted in the formation of a relationship to the book illustrations and literary heritage as a whole. Oversupply of information field was the reason for the appearance in the works of many young illustrators combinations of forms and elements known styles of fine art of past eras.

In this article, the relationship of children's classic fairy tales and illustrations in the works of local artists in the 1960-1980-ies. It is analyzed based on the above factors and characteristics.

\section{References}

1. Isakovskaya, A.Yu. (2012) Detskaya skazka v russkoy sovetskoy literature (retseptsiya mirovykh syuzhetov) [Children's fairy tale in Russian Soviet literature (the reception of world plots]. Abstract of Philology Cand. Diss. Moscow.

2. Tauber, V.I. (1975) O staroy nemetskoy skazke (Ob illyustratsii skazok brat'ev Grimm) [On the old German fairy tale (On the illustration of Brothers Grimm's fairy tales)]. Detskaya literatura. 8. pp. 75-79.

3. Tynyanov, Yu.N. (1977) Poetika. Istoriya literatury. Kino [Poetics. History of literature. Cinema]. Moscow: Nauka. pp. 310-318.

4. Podobedova, O.I. (1973) O prirode knizhnoy illyustratsii [About the nature of book illustration]. Moscow: Sovetskiy khudozhnik.

5. Bazhenova, A.E. (2015) Conflict of generations or a change of priorities in art illustration of children's books. V mire nauki i iskusstva : voprosy filologii, iskusstvovedeniya i kul'turologii. 3(46). pp. 77-81. (In Russian).

6. Lessing, G.E. (1980) Izbrannoe [Selected Works]. Translated from German by A. Gulyga. Moscow: Khudozhestvennaya literatura.

7. Lyakhov, V.N. (1978) Iskusstvo knigi. Izbrannye istoriko-teoreticheskie i kriticheskie raboty [The art of the book. Selected historical-theoretical and critical works]. Moscow: Sovetskiy khudozhnik.

8. Dianova, V.M. (2000) Postmodernistskaya filosofiya iskusstv: istoki i sovremennost' [Postmodern philosophy of art: Origins and modernity]. St. Petersburg: Petropolis. 